\title{
Poly (I:C), an agonist of toll-like receptor-3, inhibits replication of the Chikungunya virus in BEAS-2B cells
}

Yong-Gang $\mathrm{Li}^{1 *}$, Uamporn Siripanyaphinyo ${ }^{2}$, Uranan Tumkosit ${ }^{2}$, Nitchakarn Noranate ${ }^{2}$, Atchareeya A-nuegoonpipat ${ }^{3}$, Yang Pan ${ }^{1}$, Masanori Kameoka², Takeshi Kurosu', Kazuyoshi Ikuta', Naokazu Takeda ${ }^{2}$ and Surapee Anantapreecha ${ }^{3}$

\begin{abstract}
Background: Double-stranded RNA (dsRNA) and its mimic, polyinosinic acid: polycytidylic acid [Poly (I:C)], are recognized by toll-like receptor 3 (TLR3) and induce interferon (IFN)- $\beta$ in many cell types. Poly (I:C) is the most potent IFN inducer. In in vivo mouse studies, intraperitoneal injection of Poly (I:C) elicited IFN- $\alpha / \beta$ production and natural killer (NK) cells activation. The TLR3 pathway is suggested to contribute to innate immune responses against many viruses, including influenza virus, respiratory syncytial virus, herpes simplex virus 2, and murine cytomegalovirus. In Chikungunya virus (CHIKV) infection, the viruses are cleared within 7-10 days postinfection before adaptive immune responses emerge. The innate immune response is important for CHIKV clearance.

Results: The effects of Poly (I:C) on the replication of CHIKV in human bronchial epithelial cells, BEAS-2B, were studied. Poly (I:C) suppressed cytopathic effects (CPE) induced by CHIKV infection in BEAS-2B cells in the presence of Poly (I:C) and inhibited the replication of CHIKV in the cells. The virus titers of Poly (I:C)-treated cells were much lower compared with those of untreated cells. CHIKV infection and Poly (l:C) treatment of BEAS-2B cells induced the production of IFN- $\beta$ and increased the expression of anti-viral genes, including IFN- $\alpha$, IFN- $\beta$, MxA, and OAS. Both Poly (I:C) and CHIKV infection upregulate the expression of TLR3 in BEAS-2B cells.
\end{abstract}

Conclusions: CHIKV is sensitive to innate immune response induced by Poly (I:C). The inhibition of CHIKV replication by Poly $(\mathrm{I}: \mathrm{C})$ may be through the induction of TLR3, which triggers the production of IFNs and other anti-viral genes. The innate immune response is important to clear CHIKV in infected cells.

Keywords: Chikungunya virus, Poly (I:C), BEAS-2B cells, TLR3

\section{Introduction}

Chikungunya virus (CHIKV), the causative agent for Chikungunya fever, was first described in 1952 during an epidemic in Tanzania, East Africa [1,2]. CHIKV is a positive-sense single-strand RNA virus belonging to the genus Alphavirus of the family Togaviridae, and it is maintained in two distinct transmission cycles, a sylvatic cycle and a human-mosquito-human cycle. The scale of epidemics of the former is smaller and is mainly confined within African countries, involving primates such

\footnotetext{
* Correspondence: yonggang@biken.osaka-u.ac.jp

'Department of Virology, Research Institute for Microbial Diseases, Osaka University, Osaka 565-0871, Japan

Full list of author information is available at the end of the article
}

as monkeys and forest-dwelling Aedes mosquitoes [3]. CHIKV is mainly transmitted by Aedes aegypti and Aedes albopictus. CHIKV epidemics have often been characterized by long interepidemic (more than 10 years) periods in many parts of Southern and Southeast Asia [4-7]. During the past 8 years, major outbreaks have occurred among islands in the Indian Ocean, with Reunion Island being one of the most severely hit islands. Onethird of its population were infected, and more than 240 people died [8-12]. The symptoms of Chikungunya generally start 4-7 d after the bite. Acute infection lasts 110 days and is characterized by a painful polyarthralgia, high fever, asthenia, headache, vomiting, rash, and myalgia $[13,14]$. CHIKV infection has affected as many as 
3-4 million people in the Indian Ocean zone, and it spread to Europe in 2005-2007. This disease has recently received considerable attention in Thailand [15-19].

CHIKV transmission is rapid and extensive; however, humans are not defenseless, and in fact, CHIKV is efficiently cleared within 4-7 days after infection in vivo [20-22]. As a typical adaptive immune response, such as CHIKV-specific B-cell and T-cell activation, requires at least 1 week for development, the innate immune system seems to control CHIKV infection [23]. CHIKV is known to infect many different cell types, including fibroblasts and epithelial and endothelial cells in vitro [24] and fibroblast cells in vivo [25]; however, epithelial cells are armed with various mechanisms that are able to sense viral components and initiate intracellular signal transduction to respond rapidly to viral infections [26]. Polyinosinic: polycytidylic acid [Poly (I:C)], a synthetic double-stranded RNA (dsRNA) analog, is an immunostimulant that acts as the most potent interferon (IFN) inducer [27]. In in vivo mouse studies, intraperitoneal injection of Poly (I:C) elicited IFN- $\alpha / \beta$ production and natural killer (NK) cells activation [28,29]. Poly (I:C) is known to interact with toll-like receptor 3 (TLR3), which is expressed in the membrane of B-cells, macrophages, and dendritic cells.

TLRs are a member of the family of host innate immune receptors, and they are essential for detecting pathogen-associated molecular patterns. TLRs are transmembrane signaling proteins designed to specifically recognize various proteins, carbohydrates, lipids, and nucleic acids of invading microorganisms. When a TLR is activated, it triggers immune and inflammatory responses to infectious agents [30]. The TLR3 pathway contributes to an innate immune response against many viruses, including influenza virus [31], respiratory syncytial virus [32], herpes simplex virus 2 [33], and murine cytomegalovirus [34]. The detection of viral dsRNA and Poly $(\mathrm{I}: \mathrm{C})$ in the cytosol is mediated through the helicase family members retinoic-acid-inducible gene I (RIG-I) and melanoma-differentiation-associated gene 5 (MDA5), thus allowing the host to sense directly an intracellular viral infection in a TLR3-independent way $[35,36]$. In vitro studies have shown that RIG-I and MDA-5 are both capable of responding to Poly(I:C) and RNA viruses [37].

In this study, Poly (I:C) was used to examine the innate immune response in vitro. We found that Poly (I:C) suppressed the cytopathic effect (CPE) induced by CHIKV infection and inhibited the replication of CHIKV in human bronchial epithelial-derived cells, BEAS-2B, by inducing the expression of IFNs and interferon-inducible intracellular antiviral factor genes, including OAS and MxA. Based on our results, we concluded that the CHIKV was sensitive to IFNs and that the innate immune response plays an important role in the clearance of CHIKV.

\section{Results}

Poly (I:C) suppressed CPE induced by CHIKV infection

BEAS-2B cells were seeded in 6-well plates $\left(1 \times 10^{6}\right.$ cells/ well) one day before Poly (I:C) treatment. One hour before infection at multiplicity of infection (MOI) 0.01, 1, or 5 , the cells were pre-treated with $4 \mu \mathrm{g} / \mathrm{ml}$ of Poly (I: C) or left untreated. After adsorption, the cells were maintained in the medium with or without Poly (I: C) $(4 \mu \mathrm{g} / \mathrm{ml})$. The CPE was observed at 24,48 , and $72 \mathrm{~h}$ postinfection (p.i.) under a microscope. No CPE was found in Poly (I:C)-treated cells at 24 or $48 \mathrm{~h}$ p.i., even when MOI 5 was used. Although CPE was found in the Poly (I:C)-treated cells at $72 \mathrm{~h}$ p.i., it was less significant compared with that of untreated cells (Figure 1), demonstrating that Poly (I:C) treatment appeared to decrease CPE induced by CHIKV infection. Because the protection of CPE was decreased at $72 \mathrm{~h}$ p.i., we conclude that the protection is important in the early phase of infection.

\section{Poly (I:C) inhibited replication of CHIKV in BEAS-2B cells} Since the Poly(I:C) decreased CPE in BEAS-2B cells induced by CHIKV infection, we supposed that Poly(I:C) may inhibit the replication of CHIKV. To clarify the effect of Poly (I:C) treatment, we measured the virus titers produced by Poly (I:C)-treated and mock-treated cells by plaque assay (Figure 2). The supernatant was collected at 24,48 , and $72 \mathrm{~h}$ p.i. at each MOI. The virus titers from mock-treated cells were $1.5 \times 10^{6}, 5.5 \times 10^{5}$, and $4.5 \times 10^{3} \mathrm{pfu} / \mathrm{ml}$ at MOI $0.01 ; 4.3 \times 10^{6}, 1 \times 10^{6}$, and $5 \times 10^{4}$ $\mathrm{pfu} / \mathrm{ml}$ at MOI $1 ; 3.5 \times 10^{8}, 6.9 \times 10^{7}$, and $3 \times 10^{5} \mathrm{pfu} / \mathrm{ml}$ at MOI 5 at 24, 48, and $72 \mathrm{~h}$ p.i., respectively. The virus titers of the supernatant from Poly (I:C)-treated cells were $2.5 \times 10^{2}, 1.5 \times 10^{2}$, and $1 \times 10^{2} \mathrm{pfu} / \mathrm{ml}$ at MOI 0.01 ; $2.5 \times 10^{3}, 2 \times 10^{3}$, and $6.3 \times 10^{2} \mathrm{pfu} / \mathrm{ml}$ at MOI $1 ; 2 \times 10^{6}$, $6 \times 10^{5}$, and $5.5 \times 10^{3} \mathrm{pfu} / \mathrm{ml}$ at MOI 5 at 24,48 , and $72 \mathrm{~h}$ p.i., respectively, indicating that Poly (I:C) treatment significantly lowers the virus titers. With either Poly (I:C) treatment or non-treatment, the virus titers showed a high peak at $24 \mathrm{~h}$ p.i. in the infections with the same MOIs and a trend to decrease at 48 and $72 \mathrm{~h}$ p.i. These results indicated that Poly $(\mathrm{I}: \mathrm{C})$ inhibited the replication of CHIKV in BEAS-2B cells. This is probably because IFN- $\beta$ induced by Poly (I:C) treatment plays a role, as described previously [31].

Induction of IFN- $\beta$ and stimulation of TLR3 expression in BEAS-2B cells by poly (I:C) treatment or CHIKV infection Poly $(\mathrm{I}: \mathrm{C})$ is a strong IFN inducer. The effects of Poly (I:C) treatment on CHIKV infection in BEAS-2B cells may be due to the production of IFNs. To elucidate 


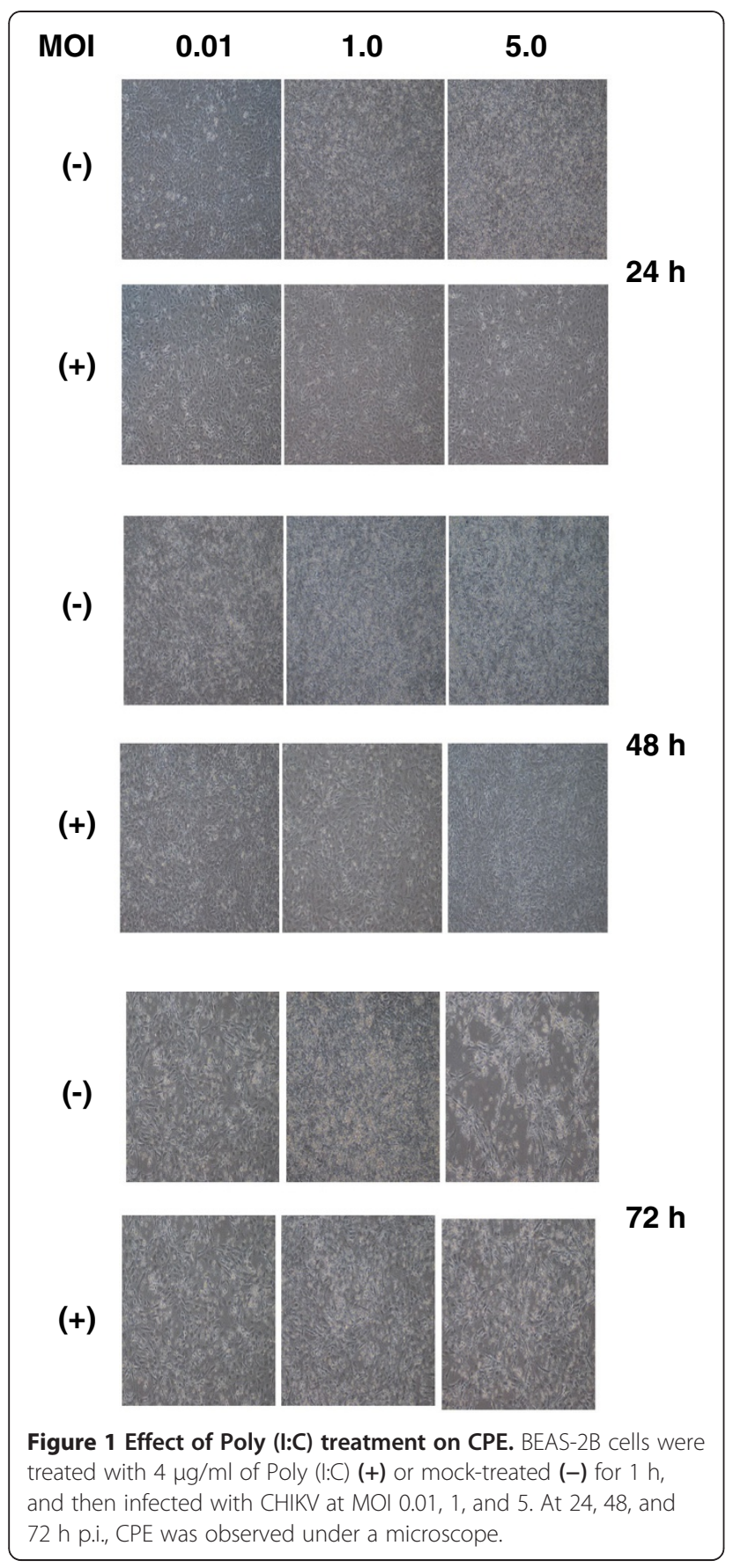

the level of IFN- $\beta$, we treated BEAS-2B cells with $4 \mu \mathrm{g} / \mathrm{ml}$ of Poly (I:C) and measured the amount of IFN- $\beta$ by ELISA. The concentration of IFN- $\beta$ in the supernatant at $0,2,4,8,16$, and 24 h p.i. was 490.60 , 681.69, 984.61, 947.82, 736.91, and $710.54 \mathrm{pg} / \mathrm{ml}$, respectively, indicating that Poly $(\mathrm{I}: \mathrm{C})$ treatment induced the secretion of IFN- $\beta$. The IFN- $\beta$ level reached a peak at $4 \mathrm{~h}$ during the treatment (Figure $3 \mathrm{~A}$ ). The IFN- $\beta$ was also induced by CHIKV infection (MOI 0.8) and reached a peak at 24 hours p.i. The concentration at $0,2,4,8,16$, and $24 \mathrm{~h}$ p.i. was $501.54,526.67,547.23$, 907.43, 1585.95, and $2614.92 \mathrm{pg} / \mathrm{ml}$, respectively, (Figure 3B). TLR3 was known as a receptor for dsRNA $[38,39]$, and upon recognition of dsRNA, TLR3 transmits signals that activate the transcript factors IFR-3, $\mathrm{NF}-\triangle \mathrm{B}$, and AP-1, leading to the induction of type I IFN [40] [41]. The level of TLR3 expression examined by $\mathrm{PCR}$ is shown in Figure 3C. The expression of TLR3 mRNA was upregulated by both Poly (I:C) treatment and CHIKV infection after 24 hours. The induction of IFN- $\beta$ may be triggered through the upregulated expression of TLR3.

\section{Induction of IFN- $\alpha$, IFN- $\beta, M x A$, and OAS genes}

One unique feature of TLR3 is to trigger the induction of the type I IFNs (IFN- $\alpha / \beta)$. In addition TLR3 is known to induce the expression of interferon-inducible intracellular antiviral factors including OAS and MxA [42,43]. We examined the expression of mRNA of these genes using RT-PCR. As shown in Figure 4, Poly (I:C) treatment stimulated the induction of IFN- $\beta$ mRNA, and a significant upregulation was observed at $2 \mathrm{~h}$ post treatment. The expression level was still apparent, albeit at a lower level, at 4 and $8 \mathrm{~h}$ post treatment. A significant upregulation of IFN- $\alpha$ was observed at $16 \mathrm{~h}$ poststimulation. Exposure of BEAS-2B cells to Poly (I:C) induced time-dependent expression of MxA and OAS mRNA; however, unlike IFN- $\alpha / \beta$, the levels of these two transcripts remained elevated $4,8,16$, and 24 h poststimulation (Figure 4.) These results indicated that Poly (I:C) induced the anti-viral genes that may contribute to the inhibition of CHIKV replication.

\section{Discussion}

The innate immune response is the first barrier against the viruses [44], initiated within hours after the viruses bind to the receptor, and it plays a central role in the detection of invading pathogens. The innate immune system responds through activating inflammatory and antiviral defense mechanisms against the infectious agents [45]. Innate immunity involves the induction of many factors, including IFNs- $\alpha / \beta$, which induce a range of antiviral processes. In infected cells, it is believed that the proximal inducer of IFNs- $\alpha / \beta$ is intracellular dsRNA generated as an intermediate during viral replication [38].

During virus replication, not only dsRNA but also single-stranded RNA (ssRNA) molecules are recognized as intermediate by TLRs expressed in dendritic cells, natural killer cells, and macrophages, as well as in epithelium [46]. The dsRNA triggers a series of events culminating in the activation of PKR and other kinases. Phosphorylation of the substrates of these 


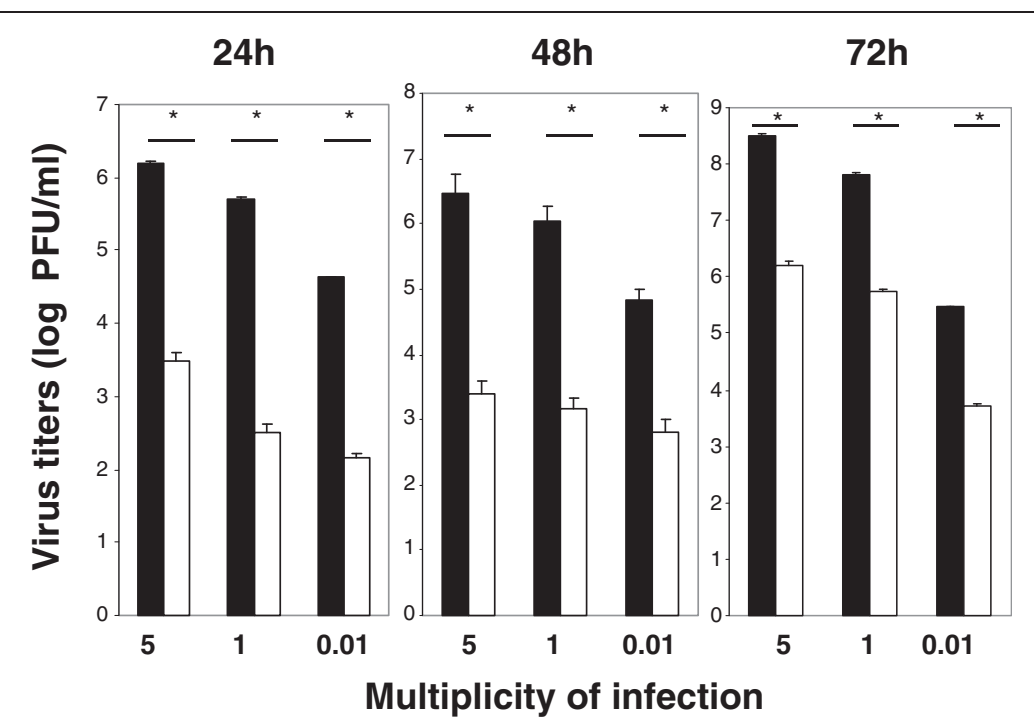

Figure 2 Effect of Poly (I:C) treatment on CHIKV growth. BEAS-2B cells were treated with $4 \mu \mathrm{g} / \mathrm{ml}$ of Poly (I:C) ( $\square$ ) or mock-treated ( $\square$ ) for $1 \mathrm{~h}$, and then infected with CHIKV at MOI 0.01, 1, and 5. At 24, 48, and $72 \mathrm{~h} \mathrm{p.i.,} \mathrm{the} \mathrm{virus} \mathrm{titer} \mathrm{in} \mathrm{the} \mathrm{supernatant} \mathrm{was} \mathrm{measured} \mathrm{by} \mathrm{a} \mathrm{plaque} \mathrm{assay.}$ *P $<0.01$ by Student's unpaired $t$-test.

enzymes results in the translocation of transcription factors, NF- $邓 \mathrm{~B}$ and IRF-3, from the cytoplasm to the nucleus, where they bind to the IFN- $\beta$ promoter to form a transcription complex that ultimately drives IFN- $\beta$ production $[47,48][49,50]$. Several in vitro studies have demonstrated that Poly (I:C), a TLR3 agonist, induces antiviral responses through the induction of IFN- $\beta$ [51].
In the present study, we demonstrated that following Poly (I:C) treatment, BEAS-2B cells produced antimicrobial factors IFN- $\beta$, OAS, and MxA, which may constitute a highly specific and potent barrier against CHIKV infection. Poly (I:C) is known to markedly upregulate the IFN- $\beta$ mRNA level in a dose-dependent manner in mouse osteoblastic MC3T3-E1 cells [52]. Similarly, trophoblast cells are known to express and secrete
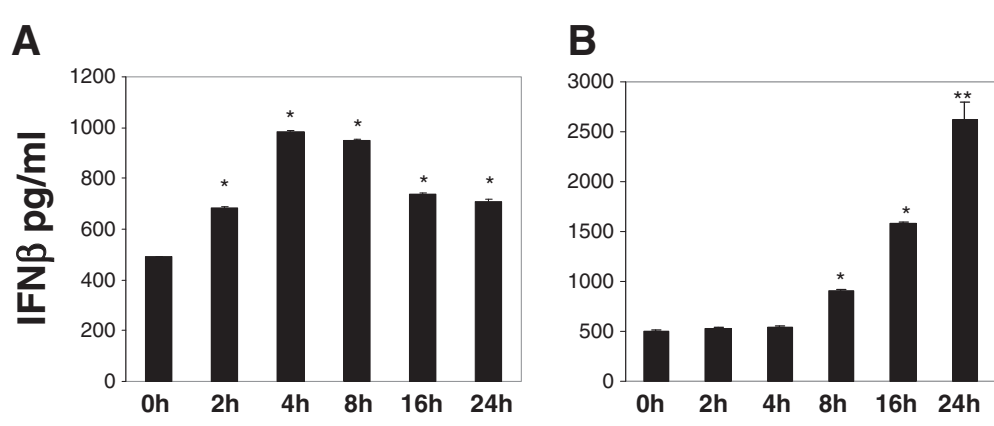

C

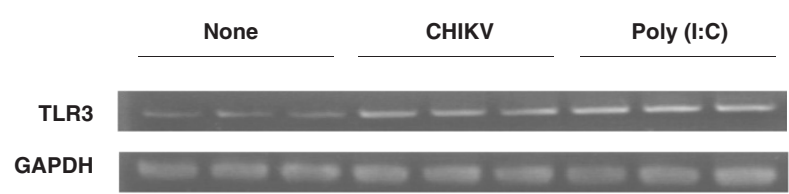

Figure 3 Induction of IFN- $\beta$ and expression of TLR3 in BEAS-2B cells treated with Poly (I:C) or infected with CHIKV. (A) BEAS-2B cells were incubated in the presence of $4 \mu \mathrm{g} / \mathrm{ml}$ of Poly $(\mathrm{I}: \mathrm{C})$, and IFN- $\beta$ secreted in the medium was measured by an ELISA. The samples were collected at $0,2,4,8,16$, and 24 p.i. (B) BEAS-2B cells were infected with CHIKV at MOI 0.8. IFN- $\beta$ in the medium was measured by an ELISA at 0 , $2,4,8,16$, and 24 h p.i.. * $P<0.05$ : ** $P<0.01$ relative to the $0 \mathrm{~h}$ time point. (C) Expression of TLR3 in BEAS-2B cells was detected by RT-PCR. The cells were incubated with $4 \mathrm{\mu g} / \mathrm{ml}$ of Poly (I:C) or infected with CHIKV at MOI 0.8. Total RNA was extracted from the cells at $24 \mathrm{~h}$ p.i., and TLR3 mRNA was amplified by RT-PCR. The products were analyzed by agarose gel electrophoresis. A representative result of the experiment performed in triplicate is shown. 


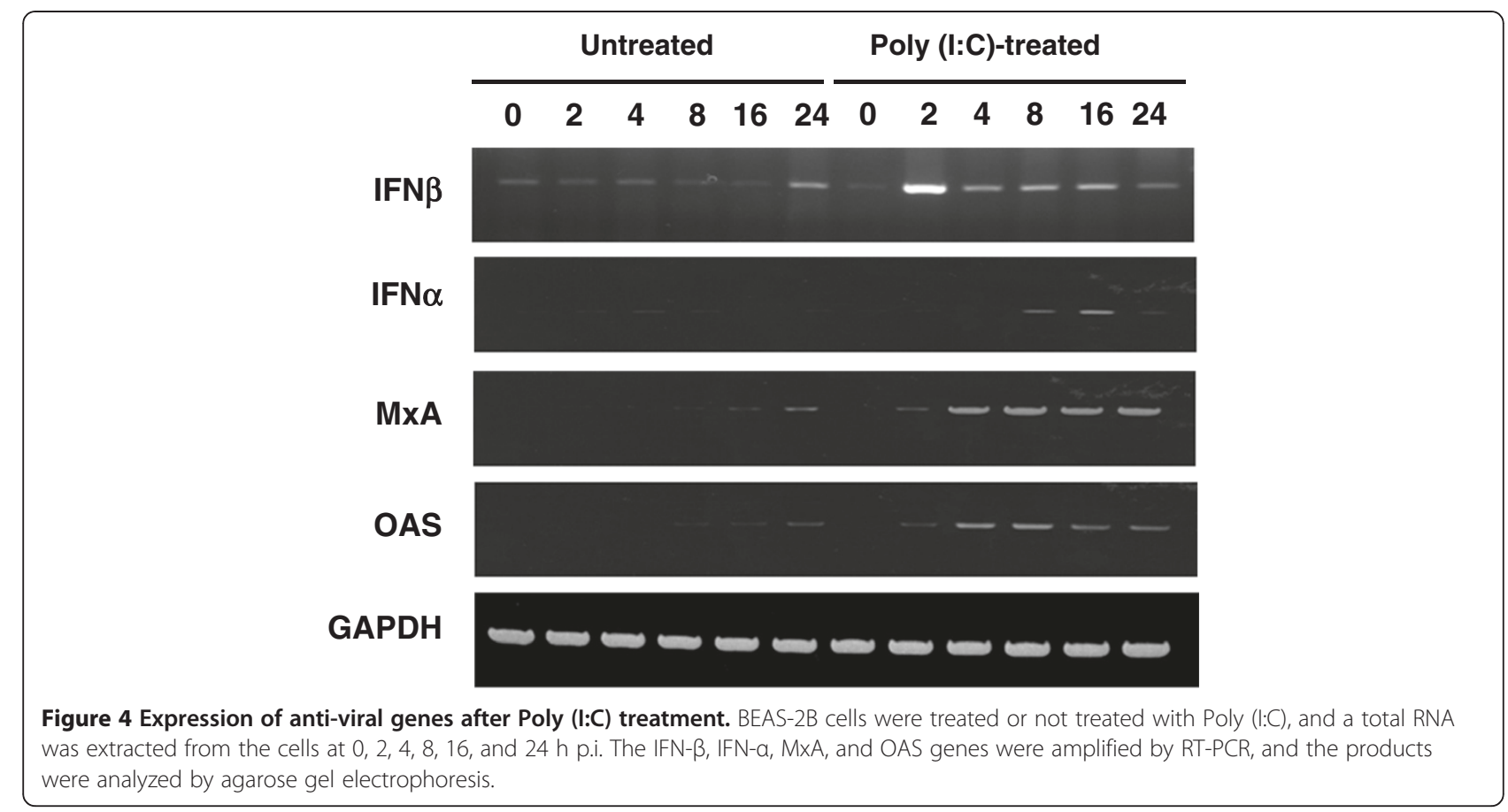

antiviral factors, such as OAS, MxA, and APOBEC3G, by Poly (I:C) [53]. Poly (I:C) treatment also inhibited the multiplication of xenotropic baboon type $\mathrm{C}$ endogenous retrovirus M7 in chronically infected human AV3-M7 cells [54] and human immunodeficiency virus amplification in dendritic cells via type I IFN-mediated activation of APOBEC3G [55].

Based on the results of the present study, we conclude that both Poly (I:C) and CHIKV infection enhanced the expression of TLR3. The stimulation of TLR3 by dsRNA transduces signals to activate the transcription factors NF-ҚB and IRF/interferon-sensitive response element (ISRE) via myeloid differentiation factor 88 (MyD88)independent signaling pathways, which involve a distinct adaptor molecule, namely the Toll-interleukin (IL)-1 receptor (TIR) domain containing adaptor-inducing IFN- $\beta$ (TRIF), also called the TIR domain containing adaptor molecule 1 (TICAM-1) [56,40]. This molecule elicits an antiviral response, especially through the production of IFNs- $\alpha / \beta$ [57]. Therefore, IFNs could contribute to decrease the CPE and inhibit the replication of CHIKV through TLR3 stimulation. Similar phenomena were reported in influenza virus in BEAS-2B cells. Both Poly $(\mathrm{I}: \mathrm{C})$ and influenza virus infection induced IFN- $\beta$ [31]. The replication of CHIKV is controlled by IFNs- $\alpha / \beta$ [24], which is critically dependent on the action of nonhematopoietic cells through the induction of one or more IFN-stimulated genes (ISGs) [58]. Therefore, induction of IFNs and antiviral genes observed in this study could contribute to the Poly (I:C)-mediated suppression of CPE and inhibition of the replication of CHIKV in BEAS-2B cells.

Poly (I:C) was widely used as an adjuvant for vaccine research. Poly (I:C)-combined intranasal vaccine protected mice against influenza virus infection, including that due to highly pathogenic H5N1 [59-61]. Synthetic dsRNA is adjuvant for the induction of $\mathrm{T}$ helper 1 and humoral immune response to human papillomavirus in rhesus macaques [62]. Therefore, Poly (I:C) could be an adjuvant for CHIKV vaccine, which can increase the immune response in humans to clear the CHIKV.

\section{Conclusions}

CHIKV is sensitive to innate immune response induced by Poly (I:C). Poly (I:C) decreased CPE and inhibited the CHIKV replication in BEAS-2B cells. The Poly (I:C) inhibition of CHIKV replication may be through the induction of TLR3, which triggers the production of IFNs and other anti-viral genes, such as MxA and OAS. The innate immune response is important to clear CHIKV in infected cells.

\section{Materials and methods}

Viruses, cells, and reagents

Chikungunya viruses (Ross Strain) were propagated in Vero-E6 (Vero) cells. The virus titer was measured by a plaque assay. BEAS-2B, a SV-40-transformed airway bronchial epithelial cell line, was purchased from American Type Culture Collection (Manassas, VA). Cells were 
maintained in RPMI-1640 supplemented with 10\% FCS. All experiments were performed in a biosafety level 3 containment laboratory. Poly (I:C) was purchased from Sigma-Aldrich (St. Louis, MO).

\section{RT-PCR}

Total RNA was extracted from the cells by using TRIzoL (Invitrogen, Carlsbad, CA) according to the manufacturer's protocol. RT was performed using $3.5 \mu \mathrm{g}$ of total RNA. PCR was performed using an INF- $\alpha$ forward primer (5'-TTTCTCCTGCCTGAAG GACAG-3') and an INF- $\alpha$ reverse primer (5'TCTCATGATTTCTGCTCTGACA-3'), a IFN- $\beta$ forward primer (5'-CTGTGGCAATTGAATGGGAGGC $-3^{\prime}$ ) and a IFN- $\beta$ reverse primer (5'-CAGGCACAGT GACTGTCCTCCTT-3'), a MxA forward primer (5'CATACTGCGAGGAGATCCTCCTT-3') and a MxA reverse primer (5'-AGCATCCGAAATCTCAATCTCGTA -3'), a OAS forward primer (5'-AGAATGTCAGACACT GATCGACGA-3') and a OAS reverse primer (5'TGTTCCCAGGCATACACCGTA-3'), a TLR3 forward primer (5'-AAATTGGGCAAGAACTCACAGG-3') and a TLR3 reverse primer (5'-GTGTTTCCAGAGCC GTGCTAA-3'), and a GAPDH forward primer (5'-CACCACCAACTGCTTAGCAC-3') and a GAPDH reverse primer (5'-CCCTGTTGCTGTAGCCAAAT-3'). Amplification products were resolved on $1.5 \%$ agarose gel containing ethidium bromide.

\section{Plaque assay}

Vero cells were seeded at $2.5 \times 10^{5}$ cells per well in 24 wells plates, incubated at $37^{\circ} \mathrm{C}$ overnight, and washed once with phosphate buffered saline (PBS). Ten-fold serial dilutions of the virus mixture were prepared in Hanks buffer (Sigma-Aldrich), and then $0.1 \mathrm{ml}$ of the mixture was inoculated into each well and incubated for $1 \mathrm{~h}$ at $37^{\circ} \mathrm{C}$, during which we agitated the plate every 15 minutes. After adsorption for $1 \mathrm{~h}$, the plate was washed with PBS three times, and $1 \mathrm{ml}$ of DMEM containing 2\% carboxymethyl cellulose (W/V) (Sigma-Aldrich) and 5\% FBS was layered onto the cells. The plates were incubated in a humidified incubator at $37^{\circ} \mathrm{C}$ with $5 \% \mathrm{CO}_{2}$ for 3 days. The overlay was removed and washed with PBS. Plaques were visualized by staining the monolayer with $1 \mathrm{ml} 0.5 \%$ crystal violet containing $10 \%$ formaldehyde (Sigma-Aldrich) for $2 \mathrm{~h}$ at room temperature. The virus plaques were counted after thorough washing with tap water.

\section{Cytokine measurements}

The concentration of human IFN- $\beta$ in cell culture supernatants was determined by using DuoSet Elisa kits (R\&D Systems, Minneapolis, MN).

\section{Competing interests}

The authors declare that they have no competing interests.

\section{Authors' contributions}

YG. Li and SA conceived and designed the experiment. US, UT, NN, AA, YP. MK, KT. Performed the experiments. KI, NT. YG. LI and SA analyzed the data and wrote the paper. All authors read and approved the final manuscript.

\section{Acknowledgements}

This study was supported, in part, by the program of the Founding Research Center for Emerging and Reemerging Infectious Diseases, which was launched through a project commissioned by the Ministry of Education, Cultures, Sports, Science and Technology of Japan.

\section{Author details}

${ }^{1}$ Department of Virology, Research Institute for Microbial Diseases, Osaka University, Osaka 565-0871, Japan. ${ }^{2}$ Section of Viral Infections, Thailand-Japan Research Collaboration Center on Emerging and Re-emerging Infections, Nonthaburi 11000, Thailand. ${ }^{3}$ National Institute of Health, Department of Medical Sciences, Ministry of Public Health, Nonthaburi 11000, Thailand.

Received: 24 June 2011 Accepted: 1 June 2012

Published: 14 June 2012

\section{References}

1. Lumsden WH: An epidemic of virus disease in Southern Province, Tanganyika Territory, in 1952-53. II. General description and epidemiology. Trans R Soc Trop Med Hyg 1955, 49:33-57.

2. Robinson MC: An epidemic of virus disease in Southern Province, Tanganyika Territory, in 1952-53. I. Clinical features. Trans R Soc Trop Med Hyg 1955, 49:28-32.

3. Mclntosh B M JPGaDSI: Rural epidemic of Chikungunya in South Africa with involvement of aedes (Diceromyia) furcifer (Edwards) and baboons: S. Afr: J Sci 1977, 73:267-269.

4. Burke CW, Gardner CL, Steffan JJ, Ryman KD, Klimstra WB: Characteristics of alpha/beta interferon induction after infection of murine fibroblasts with wild-type and mutant alphaviruses. Virology 2009, 395:121-132.

5. Lam SK, Chua KB, Hooi PS, Rahimah MA, Kumari S, Tharmaratnam M, Chuah SK, Smith DW, Sampson IA: Chikungunya infection-an emerging disease in Malaysia. Southeast Asian J Trop Med Public Health 2001, 32:447-451.

6. Munasinghe DR, Amarasekera PJ, Fernando CF: An epidemic of denguelike fever in Ceylon (chikungunya-a clinical and haematological study. Ceylon Med J 1966, 11:129-142.

7. Pavri K: Disappearance of Chikungunya virus from India and South East Asia. Trans R Soc Trop Med Hyg 1986, 80:491.

8. Chastel C: Chikungunya virus: its recent spread to the southern Indian Ocean and Reunion Island (2005-2006). Bull Acad Natl Med 2005, 189:1827-1835.

9. Enserink M: Infectious diseases. Massive outbreak draws fresh attention to little-known virus. Science 2006, 311:1085.

10. Higgs S: The 2005-2006 Chikungunya epidemic in the Indian Ocean. Vector Borne Zoonotic Dis 2006, 6:115-116.

11. Ligon BL: Reemergence of an unusual disease: the chikungunya epidemic. Semin Pediatr Infect Dis 2006, 17:99-104.

12. Paganin F, Borgherini G, Staikowsky F, Arvin-Berod C, Poubeau P: Chikungunya on Reunion Island: chronicle of an epidemic foretold. Presse Med 2006, 35:641-646.

13. Robinson MC: An epidemic of virus disease in Southern Province, Tanganyika Territory, in 1952-53. I. Clinical features. Trnas R Soc Trop Med Hyg 1955, 49:28-32.

14. Lumsden WH: An epidemic of virus disease in Southern Province, Tanganyika Territory, in 1952-53. II. General description and epidemiology. Tran R Soc Trop Med Hyg 1955, 49:33-57.

15. Pongsiri $P$, Auksornkitti $V$, Theamboonlers A, Luplertlop N, Rianthavorn $P$, Poovorawan $Y$ : Entire genome characterization of Chikungunya virus from the 2008-2009 outbreaks in Thailand. Trop Biomed 2010, 27:167-176.

16. Charrel RN, de Lamballerie $X$, Raoult D: Chikungunya outbreaks-the globalization of vectorborne diseases. N Engl J Med 2007, 356:769-771.

17. Rezza G, Nicoletti L, Angelini R, Romi R, Finarelli AC, Panning M, Cordioli P, Fortuna C, Boros S, Magurano F, et al: Infection with 
chikungunya virus in Italy: an outbreak in a temperate region. Lancet 2007, 370:1840-1846.

18. Chevillon C, Briant L, Renaud F, Devaux C: The Chikungunya threat: an ecological and evolutionary perspective. Trends Microbio/ 2008, 16:80-88

19. Mavalankar D, Shastri P, Bandyopadhyay T, Parmar J, Ramani KV: Increased mortality rate associated with chikungunya epidemic, Ahmedabad, India. Emerg Infect Dis 2008, 14:412-415.

20. Laurent $P$, Le Roux K, Grivard P, Bertil G, Naze F, Picard M, Staikowsky F, Barau G, Schuffenecker I, Michault A: Development of a sensitive real-time reverse transcriptase $\mathrm{PCR}$ assay with an internal control to detect and quantify chikungunya virus. Clin Chem 2007, 53:1408-1414.

21. Carey DE, Myers RM, DeRanitz CM, Jadhav M, Reuben R: The 1964 chikungunya epidemic at Vellore, South India, including observations on concurrent dengue. Trans R Soc Trop Med Hyg 1969, 63:434-445.

22. Brighton SW, Prozesky OW, de la Harpe AL: Chikungunya virus infection. $A$ retrospective study of 107 cases. S Afr Med J 1983, 63:313-315.

23. Schwartz O, Albert ML: Biology and pathogenesis of chikungunya virus. Nat Rev Microbiol 2010, 8:491-500.

24. Sourisseau M, Schilte C, Casartelli N, Trouillet C, Guivel-Benhassine F, Rudnicka D, Sol-Foulon N, Le Roux K, Prevost MC, Fsihi H, et al: Characterization of reemerging chikungunya virus. PLoS Pathog 2007, 3:e89

25. Couderc T, Chretien F, Schilte C, Disson O, Brigitte M, Guivel-Benhassine F, Touret Y, Barau G, Cayet N, Schuffenecker I, et al: A mouse model for Chikungunya: young age and inefficient type-I interferon signaling are risk factors for severe disease. PLoS Pathog 2008, 4:e29.

26. Jacobs BL, Langland JO: When two strands are better than one: the mediators and modulators of the cellular responses to double-stranded RNA. Virology 1996, 219:339-349.

27. Field AK, Tytell AA, Lampson GP, Hilleman MR: Inducers of interferon and host resistance. II. Multistranded synthetic polynucleotide complexes. Proc Natl Acad Sci U S A 1967, 58:100-1010.

28. Djeu JY, Heinbaugh JA, Holden HT, Herberman RB: Role of macrophages in the augementation of mouse natural killer cell activity by poly I:C and interferon. J Immunol 1979, 122:182-188.

29. Gidlund M, Orn A, Wigzell H, Senik A, Gresser I: Enhanced NK cell activity in mice injected with interferon and interferon inducers. Nature 1978, 273:759-761.

30. Matsumoto M, Seya T: TLR3: interferon induction by double-stranded RNA including poly(l:C). Adv Drug Deliv Rev 2008, 60:805-812.

31. Guillot L, Le Goffic R, Bloch S, Escriou N, Akira S, Chignard M, Si-Tahar M: Involvement of toll-like receptor 3 in the immune response of lung epithelial cells to double-stranded RNA and influenza A virus. J Biol Chem 2005, 280:5571-5580.

32. Rudd BD, Burstein E, Duckett CS, Li X, Lukacs NW: Differential role for TLR3 in respiratory syncytial virus-induced chemokine expression. J Virol 2005 79:3350-3357.

33. Ashkar AA, Yao XD, Gill N, Sajic D, Patrick AJ, Rosenthal KL: Toll-like receptor (TLR)-3, but not TLR4, agonist protects against genital herpes infection in the absence of inflammation seen with CPG DNA. J Infect Dis 2004, 190:1841-1849.

34. Tabeta K, Georgel P, Janssen E, Du X, Hoebe K, Crozat K, Mudd S, Shamel L, Sovath S, Goode J, et al: Toll-like receptors 9 and 3 as essential components of innate immune defense against mouse cytomegalovirus infection. Proc Natl Acad Sci U S A 2004, 101:3516-3521.

35. Gitlin L, Barchet W, Gilfillan S, Cella M, Beutler B, Flavell RA, Diamond MS, Colonna M: Essential role of mda-5 in type I IFN responses to polyriboinosinic:polyribocytidylic acid and encephalomyocarditis picornavirus. Proc Natl Acad Sci U S A 2006, 103:8459-8464.

36. Yoneyama M, Kikuchi M, Natsukawa T, Shinobu N, Imaizumi T, Miyagishi M, Taira K, Akira S, Fujita T: The RNA helicase RIG-I has an essential function in double-stranded RNA-induced innate antiviral responses. Nat Immunol 2004, 5:730-737

37. Yoneyama M, Kikuchi M, Matsumoto K, Imaizumi T, Miyagishi M, Taira K, Foy E, Loo YM, Gale M Jr, Akira S, et al: Shared and unique functions of the DExD/H-box helicases RIG-I, MDA5, and LGP2 in antiviral innate immunity. J Immunol 2005, 175:2851-2858.

38. Alexopoulou L, Holt AC, Medzhitov R, Flavell RA: Recognition of doublestranded RNA and activation of NF-kappaB by Toll-like receptor 3. Nature 2001, 413:732-738.
39. Matsumoto M, Kikkawa S, Kohase M, Miyake K, Seya T: Establishment of a monoclonal antibody against human Toll-like receptor 3 that blocks double-stranded RNA-mediated signaling. Biochem Biophys Res Commun 2002, 293:1364-1369.

40. Yamamoto M, Sato S, Hemmi H, Hoshino K, Kaisho T, Sanjo H, Takeuchi O, Sugiyama M, Okabe M, Takeda K, Akira S: Role of adaptor TRIF in the MyD88-independent toll-like receptor signaling pathway. Science 2003, 301:640-643.

41. Oshiumi H, Matsumoto M, Funami K, Akazawa T, Seya T: TICAM-1, an adaptor molecule that participates in Toll-like receptor 3-mediated interferon-beta induction. Nat Immunol 2003, 4:161-167.

42. Samuel CE: Antiviral actions of interferons. Clin Microbiol Rev 2001 14:778-809 table of contents.

43. Takeuchi $\mathrm{O}$, Hemmi H, Akira S: Interferon response induced by Toll-like receptor signaling. J Endotoxin Res 2004, 10:252-256

44. Le Bon A, Tough DF: Links between innate and adaptive immunity via type I interferon. Curr Opin Immunol 2002, 14:432-436.

45. Koyama S, Ishii KJ, Coban C, Akira S: Innate immune response to viral infection. Cytokine 2008, 43:336-341.

46. Sen GC, Sarkar SN: Transcriptional signaling by double-stranded RNA: role of TLR3. Cytokine Growth Factor Rev 2005, 16:1-14.

47. Juang YT, Lowther W, Kellum M, Au WC, Lin R, Hiscott J, Pitha PM: Primary activation of interferon $A$ and interferon $B$ gene transcription by interferon regulatory factor 3. Proc Natl Acad Sci U S A 1998, 95:9837-9842.

48. Lin R, Heylbroeck C, Pitha PM, Hiscott J: Virus-dependent phosphorylation of the IRF-3 transcription factor regulates nuclear translocation, transactivation potential, and proteasome-mediated degradation. $\mathrm{Mol}$ Cell Biol 1998, 18:2986-2996.

49. Wathelet MG, Lin CH, Parekh BS, Ronco LV, Howley PM, Maniatis T: Virus infection induces the assembly of coordinately activated transcription factors on the IFN-beta enhancer in vivo. Mol Cell 1998, 1:507-518.

50. Yoneyama M, Suhara W, Fukuhara Y, Fukuda M, Nishida E, Fujita T: Direct triggering of the type I interferon system by virus infection: activation of a transcription factor complex containing IRF-3 and CBP/p300. EMBO J 1998, 17:1087-1095.

51. Kumar A, Zhang J, Yu FS: Toll-like receptor 3 agonist poly(l:C)-induced antiviral response in human corneal epithelial cells. Immunology 2006 117:11-21.

52. Nakamura K, Deyama Y, Yoshimura Y, Suzuki K, Morita M: Toll-like receptor 3 ligand-induced antiviral response in mouse osteoblastic cells. Int J Mol Med 2007, 19:771-775.

53. Abrahams VM, Schaefer TM, Fahey JV, Visintin I, Wright JA, Aldo PB, Romero R, Wira CR, Mor G: Expression and secretion of antiviral factors by trophoblast cells following stimulation by the TLR-3 agonist, Poly(l: C) Hum Reprod 2006, 21:2432-2439.

54. Chelbi-Alix MK, Belforte B, Saal F, Lasneret J, Peries J, Thang MN: The effects of poly $(\mathrm{I})$.poly $(\mathrm{C} 12 \mathrm{U})$ and interferon on the multiplication of a mammalian type C retrovirus in human cells. J Gen Virol 1992, 73(Pt 9):2291-2297.

55. Trapp S, Derby NR, Singer R, Shaw A, Williams VG, Turville SG, Bess JW Jr, Lifson JD, Robbiani M: Double-stranded RNA analog poly $(\mathrm{l}: \mathrm{C})$ inhibits human immunodeficiency virus amplification in dendritic cells via type I interferon-mediated activation of APOBEC3G. J Virol 2009, 83:884-895.

56. Yamamoto M, Sato S, Mori K, Hoshino K, Takeuchi O, Takeda K, Akira S: Cutting edge: a novel Toll/IL-1 receptor domain-containing adapter that preferentially activates the IFN-beta promoter in the Toll-like receptor signaling. J Immunol 2002, 169:6668-6672.

57. Li K, Chen Z, Kato N, Gale M Jr, Lemon SM: Distinct poly(I-C) and virusactivated signaling pathways leading to interferon-beta production in hepatocytes. J Biol Chem 2005, 280:16739-16747.

58. Schilte C, Couderc T, Chretien F, Sourisseau M, Gangneux N, GuivelBenhassine F, Kraxner A, Tschopp J, Higgs S, Michault A, et al: Type I IFN controls chikungunya virus via its action on nonhematopoietic cells. J Exp Med 2009, 207:429-442.

59. Ichinohe T, Watanabe I, Ito S, Fujii H, Moriyama M, Tamura S, Takahashi H, Sawa H, Chiba J, Kurata T, et al: Synthetic double-stranded RNA poly(l:C) combined with mucosal vaccine protects against influenza virus infection. J Virol 2005, 79:2910-2919.

60. Ichinohe T, Watanabe I, Tao E, Ito S, Kawaguchi A, Tamura S, Takahashi H, Sawa H, Moriyama M, Chiba J, et al: Protection against influenza virus 
infection by intranasal vaccine with surf clam microparticles (SMP) as an adjuvant. J Med Virol 2006, 78:954-963.

61. Ichinohe T, Ainai A, Tashiro M, Sata T, Hasegawa H: Polyl:polyC12U adjuvant-combined intranasal vaccine protects mice against highly pathogenic H5N1 influenza virus variants. Vaccine 2009, 27:6276-6279.

62. Stahl-Hennig C, Eisenblatter M, Jasny E, Rzehak T, Tenner-Racz K, Trumpfheller C, Salazar AM, Uberla K, Nieto K, Kleinschmidt J, et al: Synthetic double-stranded RNAs are adjuvants for the induction of T helper 1 and humoral immune responses to human papillomavirus in rhesus macaques. PLoS Pathog 2009, 5:e1000373.

doi:10.1186/1743-422X-9-114

Cite this article as: Li et al:: Poly (I:C), an agonist of toll-like receptor-3, inhibits replication of the Chikungunya virus in BEAS-2B cells. Virology Journal 2012 9:114.

\section{Submit your next manuscript to BioMed Central and take full advantage of:}

- Convenient online submission

- Thorough peer review

- No space constraints or color figure charges

- Immediate publication on acceptance

- Inclusion in PubMed, CAS, Scopus and Google Scholar

- Research which is freely available for redistribution 